\title{
Digestive diseases in elderly and factors associated with length of stay in the Hepatology and Gastroenterology Unit of the Campus Teaching Hospital of Lome (Togo)
}

\author{
Laté Mawuli LAWSON-ANANISSOH, Oumboma BOUGLOUGA, Aklesso BAGNY, \\ Rafiou EL-HADJI YAKOUBOU, Laconi KAAGA and Datouda REDAH
}

Received 12/6/2018 Accepted 28/9/2018

\begin{abstract}
Background - The digestive pathologies are frequent in the elderly and often have a latent and atypical symptomatology. Objective - To assess the epidemiological and evolutionary current data on digestive diseases in the elderly, and look for factors associated with length of hospital stay. Methods - Retrospective study of 10 years, including patients aged 60 and over hospitalized for digestive diseases in the Gastroenterology Department of the Campus Teaching Hospital of Lome, Togo. Results - Of 5933 hospitalized patients, there were 1054 patients (17.8\%) aged 60 years and over with a digestive pathology ( 526 men and 528 women). The average age was 69.5 years \pm 7.9 ranging from 60 to 105 years. The average length of hospital stay was 7.45 days \pm 6.2 ranging from 1 to 44 days. HIV prevalence was $2.4 \%$. In order of decreasing frequency, there were hepatobiliary pathologies $(54.3 \%)$ with a predominance of cirrhosis and liver cancer, eso-gastroduodenal pathologies (23.1\%) with predominance of ulcers, gastric cancer and esophageal cancer, intestinal pathologies $(8.7 \%)$ with a predominance of food poisoning, pancreatic pathologies $(4.2 \%)$ with a predominance of pancreatic cancer and peritoneal pathologies (1.4\%). Gastric cancer was the second digestive cancer found after liver cancer. Pancreatic head cancer was the second disease after gastric cancer which need a transfer in a surgical ward $(P=0.031)$. There were 204 deaths $(19.4 \%)$. The longest duration of hospitalization was due to gastric cancer (9.16 days). Conclusion - Hepatobiliary diseases were the most frequent and associated with a high death rate and a long hospital stay.
\end{abstract}

HEADINGS - Aged. Digestive system diseases. Hospitalization. Togo.

\section{INTRODUCTION}

The digestive pathologies are frequent in the elderly and often have a latent and atypical symptomatology ${ }^{(1)}$. Age greater than 60 represents a vulnerable area, given the structural alterations that occur and the loss of many functional reserves ${ }^{(2)}$. In sub-Saharan Africa, the scarcity of scientific work on the pathologies of the elderly and the lack of geriatric-type medical structures make it difficult to take care of the entire population ${ }^{(3)}$. In Togo ${ }^{(4)}$ where the proportion of people aged 65 and over represents $3.32 \%$ of the population in 2015 , there are no geriatric medical structures and rare are the publications on digestive pathologies in this age group ${ }^{(5,6)}$. This study was therefore conducted to clarify the current epidemiological and evolutionary data on the digestive pathologies of the elderly and to look for the factors associated with the length of stay of the elderly patient hospitalized in a unit of Hepatology and Gastroenterology.

\section{METHODS}

This was a retrospective study that focused on the files of patients aged 60 and over hospitalized in the Hepatology and Gastroenterology Unit of the Campus Teaching Hospital of Lome (Togo) from
January 1st, 2005 to December 31st, 2014. Included were all patients whose exit diagnosis included at least one digestive pathology. Incomplete files and / or patients with digestive diseases of a surgical nature from the outset and/or extra-digestive conditions were not included in the study. The studied parameters included the socio-demographic data (age, gender, profession, category of room of hospitalization), the frequency of the various digestive pathologies, their clinical manifestations as well as the mode of evolution of each pathology, the length of stay and the hospitalization period of the patient in relation to the effective start date of the health insurance of the officials of Togo (March 1st, 2012). There were three categories of hospitalization rooms: category 1 (air-conditioned room with internal shower); category 2 (air-conditioned or ventilated room with external shower) and category 3 (common room). Data entry was done with Excel 2013; the statistical analysis was done with the STATA software version 2012. The different parameters were compared using the Pearson Chi2 test or using the Fisher test and Mann-Whitney test, the significance level was $P<0.05$. For the average stay, the average comparison test (normal law) was used when the explanatory variable is binary. For the explanatory variables of more than two modalities the Anova test was carried out after verification of the conditions of validity of this test (homoscedasticity, normality, independence).

Declared conflict of interest of all authors: none

Disclosure of funding: no funding received

Hepatology and Gastroenterology Unit of the Campus Teaching Hospital of Lome, Togo.

Corresponding author: Lawson-Ananissoh Laté Mawuli. Orcid: https://orcid.org/0000-0001-9726-7024. Email: lawsonprosper@yahoo.fr 


\section{RESULTS}

Of the 5933 patients hospitalized during the study period, there were 1304 patients aged 60 years and more, of whom 1054 (17.8\%) had a digestive pathology (526 men and 528 women).

\section{General characteristics of the study population}

The mean age was 69.5 years \pm 7.9 (Extremes: 60 and 105 years). The most represented age group was 60 to 70 years old $(53.9 \%)$ as shown in FIGURE 1. On the socio-professional level, 255 patients $(24.2 \%)$ were active; 386 patients $(36.6 \%)$ were retired and 929 $(88.1 \%)$ patients were hospitalized in a Category 3 room. The human immunodeficiency virus (HIV) was found in 25 cases (11 men and 14 women) or $2.4 \%$ and the age group of 60 to 70 years was the most affected with 23 cases. Data on Comorbidities (diabetes, high blood pressure), lifestyle (alcohol and tobacco consumption) and patients' eating habits were not specified in the records.

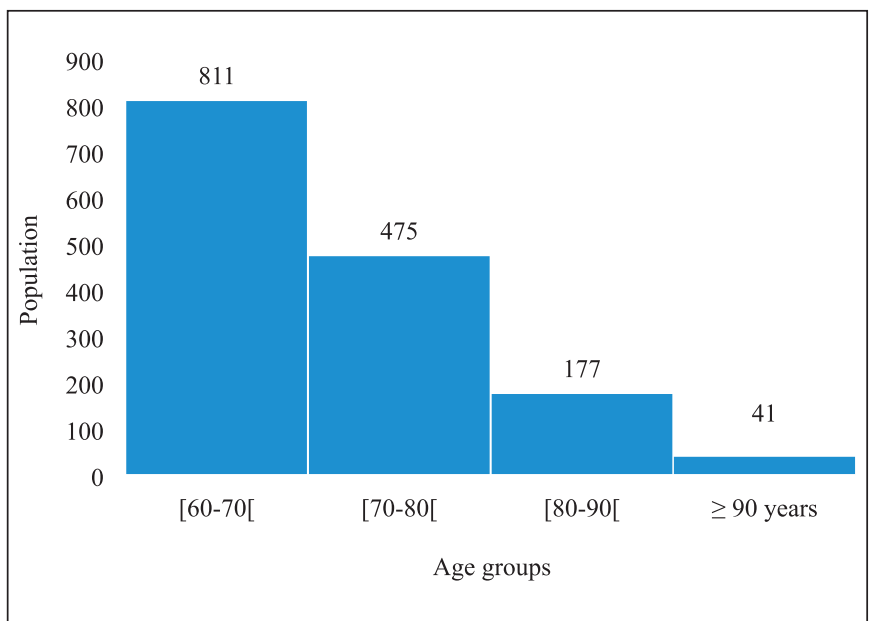

FIGURE 1. Distribution of 1504 patients by age groups.

\section{General characteristics of digestive diseases}

Hepatobiliary pathologies represented $54.3 \%$ followed by esogastroduodenal pathologies (23.1\%) as shown in TABLE 1.

\section{Special characteristics of digestive pathologies \\ - Eso-gastroduodenal pathologies}

Ulcers were found in $7.3 \%$ of cases; $6.8 \%$ of patients had an inflammatory condition. Gastric cancer was found in $5.8 \%$ of patients; esophageal cancer represented $1.2 \%$ of cases (TABLE 1). The sex ratio for oesophageal cancer was 5.5 in favor of men, and the 60 to 70 age group was the most affected with 8 cases. Gastric cancer was the second cancer found after liver cancer.

\section{- Intestinal and anal pathologies}

Diarrhea was associated with HIV in six cases. The sex ratio for colorectal cancer was 2.75 in favor of men; the 60 to 70 age group was the most affected with 11 cases. A case of rectal caustic necrosis occurred in a 70-year-old woman following an enema to treat constipation.

\section{- Hepatobiliary pathologies}

Cirrhosis was observed in $27.5 \%$ of cases; $24.6 \%$ of patients had liver cancer. Liver cancer was divided between 238 cases of hepatocarcinoma (HCC) and 21 cases of hepatic metastases whose primary tumor could not be specified (TABLE 1). Liver cancer was the first digestive cancer with a sex ratio of 1.1. Cirrhosis was found significantly in men $(P=0.035)$.

TABLE 1. Main digestive pathologies and their general evolution $(\mathrm{n}=1504)$.

\begin{tabular}{|c|c|c|}
\hline & Population (n) & Percentage (\%) \\
\hline \multicolumn{3}{|l|}{ Hepatobiliary pathologies } \\
\hline Cirrhosis & 290 & 27.5 \\
\hline Hepatocarcinoma & 238 & 22.5 \\
\hline Liver metastases & 21 & 1.9 \\
\hline Cholangiocarcinoma & 7 & 0.7 \\
\hline Toxic hepatitis & 7 & 0.7 \\
\hline Hepatic abscess & 5 & 0.5 \\
\hline Hépatonephritis & 5 & 0.5 \\
\hline \multicolumn{3}{|c|}{ Eso-gastroduodenal pathologies } \\
\hline Esophageal cancer & 13 & 1.2 \\
\hline Gastroesophageal reflux & 11 & 1.0 \\
\hline Esophagitis & 9 & 0.9 \\
\hline Mallory-Weiss syndrome & 4 & 0.4 \\
\hline Gastric cancer & 61 & 5.8 \\
\hline Gastritis & 43 & 4.1 \\
\hline Gastric ulcer & 38 & 3.6 \\
\hline Gastric polyp & 2 & 0.2 \\
\hline Cardiac cancer & 1 & 0.1 \\
\hline Bulbar ulcer & 39 & 3.7 \\
\hline Bulbo-duodenitis & 19 & 1.8 \\
\hline Bulb lymphoma & 3 & 0.3 \\
\hline \multicolumn{3}{|l|}{ Intestinal and anal pathologies } \\
\hline Food poisoning & 41 & 3.9 \\
\hline Colorectal cancer & 15 & 1.4 \\
\hline Functional colopathy & 13 & 1.2 \\
\hline Diverticulosis of the colon & 6 & 0.6 \\
\hline Colitis & 2 & 0.2 \\
\hline Rectal necrosis & 1 & 0.1 \\
\hline Hemorrhoids & 12 & 1.1 \\
\hline Anal cancer & 2 & 0.2 \\
\hline \multicolumn{3}{|l|}{ Pancreatic pathologies } \\
\hline Pancreatic cancer & 40 & 3.8 \\
\hline Chronic pancreatitis & 2 & 0.2 \\
\hline Acute pancreatitis & 2 & 0.2 \\
\hline \multicolumn{3}{|l|}{ Pathologies of the peritoneum } \\
\hline Peritoneal tuberculosis & 15 & 1.4 \\
\hline \multicolumn{3}{|l|}{ Other pathologies } \\
\hline $\begin{array}{l}\text { General evolution of } \\
\text { digestive pathologies }\end{array}$ & 87 & 8.3 \\
\hline Death & 204 & 19.4 \\
\hline Discharge & 12 & 1.1 \\
\hline Exit & 788 & 74.8 \\
\hline Transfer & 50 & 4.7 \\
\hline
\end{tabular}




\section{- Pancreatic pathologies}

Pancreatic head cancer represented $3.8 \%$ of cases as shown in TABLE 2; the sex ratio was 1.82 for men.

\section{- Pathologies of the peritoneum}

Peritoneal tuberculosis ( $\mathrm{n}=15$ or $1.4 \%$ ) was observed in the 60 to 70 age group with 13 cases and was associated with HIV in 6 cases.

\section{The evolution of different digestive pathologies and the length of stay}

The average duration of hospital stay was 7.45 days \pm 6.2 (Extreme 1 and 44 days). There were 204 deaths (19.4\%) (TABLE 1). The evolution of different digestive pathologies was not related to age $(P=0.3228)$ as shown in TABLE 2 , nor to sex $(P=0.070)$. The death rate was $37.7 \%$ for $\mathrm{HCC}$ and $36.8 \%$ for cirrhosis $(P<0.0001)$; pancreatic cancer was the second pathology after gastric cancer requiring surgical transfer $(P=0.031)$ (TABLE 2$)$. Food poisoning had a residence time of 3.22 days and the period of stay for gastric cancer was 9.16 days $(P<0.0001)$ (TABLE 3$)$. The length of stay did not present any significant variation from one age class to another (TABLE 3). Hospitalization in a category 1 room was associated with an increase in length of stay $(P=0.012)$; category 3 was associated with a decrease in length of stay $(P=0.0064)$. The average length of stay before and after March 1, 2012 was 7.31 days and 7.41 days, respectively $(P=0.139)$.

\section{DISCUSSION}

\section{The digestive pathologies of the elderly}

In order of decreasing frequency, there were hepatobiliary pathologies with a predominance of cirrhosis and liver cancer, eso-gastroduodenal pathologies with predominance of ulcers,
TABLE 3. Average length of hospital stay according to age group, pathological groups and main digestive diseases.

\begin{tabular}{lccc}
\hline & n & $\begin{array}{c}\text { Average } \\
\text { length (day) }\end{array}$ & P value \\
\hline Age groups (years) & 569 & 7.77 & 0.2080 \\
[60-70[ & 333 & 7.30 & \\
[70-80[ & 124 & 6.71 & \\
[80-90[ & 28 & 6.18 & \\
90 years and over & & & \\
& & & 0.0049 \\
Pathological groups & 574 & 8.03 & \\
Hepatobiliary pathologies & 136 & 6.01 & \\
Intestinal pathologies & 279 & 6.95 & \\
Eso-gastroduodenal pathologies & 44 & 8.27 & \\
Pancreatic pathologies & 8 & 8.25 & \\
Pathologies of the peritoneum & & & \\
& & & $<0.0001$ \\
Main digestives pathologies & & & \\
Hepatocarcinoma & 238 & 6.92 & \\
Cirrhosis & 290 & 8.96 & \\
Gastritis & 43 & 6.28 & \\
Gastric cancer & 61 & 9.16 & \\
Food poisoning & 41 & 3.22 & \\
Cancer of the head of the pancreas & 37 & 7.92 & \\
Bulbar ulcer & 39 & 7.51 & \\
Gastric ulcer & 38 & 6.68 & \\
\hline
\end{tabular}

TABLE 2. Evolution at the end of hospitalization according to digestive pathologies and age groups $(\mathrm{n}=1504)$.

\begin{tabular}{|c|c|c|c|c|c|c|c|c|c|}
\hline & \multicolumn{2}{|c|}{ Death } & \multicolumn{2}{|c|}{ Discharge } & \multicolumn{2}{|c|}{ Exit } & \multicolumn{2}{|c|}{ Transfer } & \multirow{2}{*}{$P$ value } \\
\hline & $\mathrm{n}$ & $\%$ & $\mathrm{n}$ & $\%$ & $\mathrm{n}$ & $\%$ & $\mathrm{n}$ & $\%$ & \\
\hline Age groups & & & & & & & & & $0.3228^{+}$ \\
\hline$[60-70[$ & 108 & 52.9 & 7 & 58.4 & 430 & 54.5 & 24 & 48.0 & \\
\hline$[70-80[$ & 64 & 31.4 & 3 & 25.0 & 251 & 31.9 & 15 & 30.0 & \\
\hline$[80-90[$ & 30 & 14.8 & 1 & 8.3 & 83 & 10.5 & 10 & 20.0 & \\
\hline 90 years and over & 2 & 0.9 & 1 & 8.3 & 24 & 3.1 & 1 & 2.0 & \\
\hline Total & 204 & 100 & 12 & 100 & 788 & 100 & 50 & 100 & \\
\hline Digestives pathologies & & & & & & & & & $<0.0001^{+}$ \\
\hline Hepatocarcinoma & 77 & 37.7 & 2 & 16.7 & 158 & 20.1 & 1 & 2 & \\
\hline Cirrhosis & 75 & 36.8 & 4 & 33.3 & 206 & 26.1 & 5 & 10 & \\
\hline Gastritis & 1 & 0.5 & 0 & 0.0 & 42 & 5.3 & 0 & 0.0 & \\
\hline Gastric cancer & 6 & 2.9 & 0 & 0.0 & 47 & 5.9 & 8 & 16 & \\
\hline Food poisining & 0 & 0.0 & 0 & 0.0 & 40 & 5.1 & 1 & 2 & \\
\hline Cancer of the head of the pancreas & 9 & 4.4 & 0 & 0.0 & 22 & 2.8 & 6 & 12 & \\
\hline Bulbar ulcer & 2 & 0.9 & 1 & 8.3 & 36 & 4.6 & 0 & 0.0 & \\
\hline Gastric ulcer & 1 & 0.5 & 0 & 0.0 & 36 & 4.6 & 1 & 2 & \\
\hline Other pathologies & 33 & 16.2 & 5 & 41.7 & 197 & 25 & 28 & 56 & \\
\hline Total & 204 & 100 & 12 & 100 & 788 & 100 & 50 & 100 & \\
\hline
\end{tabular}

${ }^{+}$Fisher's exact test. 
gastric cancer and esophageal cancer, intestinal pathologies with a predominance of food poisoning, pancreatic pathologies with a predominance of pancreatic cancer and peritoneal pathologies. Djibril et al. ${ }^{(5)}$ noted in order of frequency of intestinal pathologies with a predominance of food poisoning, hepatobiliaries with a predominance of decompensated cirrhosis, eso-gastroduodenal with a predominance of ulcers, anorectal, peritoneal and pancreatic. Gastrointestinal disorders represent the third cause of consultations by general practitioners among subjects older than 65 years in Western countries ${ }^{(7)}$. The data on esophageal cancer in our study were not different from those of Peghini et al. ${ }^{(8)}$ who had noted 16 cases of esophageal cancer including 6 cases in patients aged 60 and over with a predominance in the age group of 60 and 70 and that it affected men much more. This is in agreement with literature data that states that esophageal cancer in Africa is common from the fifth decade ${ }^{(8-10)}$. Zeng et al. ${ }^{(11)}$ in a comparative study of esophageal cancer in the elderly and the young subject had found a sex ratio 5 times the normal in favor of men in subjects over 70 years; the authors noted that, female gender was an independent favorable prognostic factor for esophageal cancer, which was similar to previously reported findings in United States ${ }^{(12)}$. However, the prognostic impact of sex differed between elderly patients and younger patients because gender was not an independent negative prognostic factor in patients 70 years of age or older ${ }^{(11)}$. These findings may be explained by the hypothesis that the endocrine milieu in pre- and perimenopausal females functions as a protective factor against esophageal cancer, while older postmenopausal females lose this estrogen exposure ${ }^{(13)}$. In addition, males showed a higher incidence of drinking and smoking, which are also risk factors for inducing esophageal cancer at an earlier age $^{(14)}$. Gastric cancer is one of the most common cancers of the digestive tract in the general population in Africa according to several authors ${ }^{(6,15)}$. Peghini et al. ${ }^{(8)}$ noted 72 cases of gastric cancer of which $34(47.2 \%)$ cases in patients aged 60 years and more. The frequency of gastric cancer found in the series of Djibril et al. ${ }^{(5)}$ is lower than that found in our series. Our study population consisted of patients aged 60 and more, unlike the study population of Djibril et al. ${ }^{(5)}$ who recruited patients aged 65 and more; which could explain the low frequency of gastric cancer found by Djibril et al. Bouglouga et al. ${ }^{(16)}$ noted 32 cases of gastric cancer, 14 cases $(43.7 \%)$ in patients aged 60 years and more over a period of 8 years. However, the frequency of gastric cancer in our study remains lower than that observed in the series of Kadende et al. $(37.5 \%)^{(15)}$, Diarra et al. $(48.54 \%)^{(17)}$. This disparity could be explained by the difficulty of our patients to honor the complementary examinations especially the digestive fibroscopy. In Brazil, gastric cancer was in 2014, the fourth most common cancer in men and the sixth in women; deaths from gastric cancer occurred in the majority of cases in subjects over 66 years of age ${ }^{(18)}$. The association is mainly attributed to low socioeconomic status, which increases the likelihood of transmission and reinfection of Helicobacter pylori in household clusters with large families, poor sanitation, and less frequent use of antibiotics $^{(18)}$. The retrospective nature of our present study did not allow us to analyze the factors associated with death from gastric cancer. Cirrhosis and liver cancer overcame hepatobiliary pathologies as in the Djibril et al. series ${ }^{(5)}$. Liver cancer was the first digestive cancer in our series. Bouglouga et al. ${ }^{(19)}$ noted that the main etiologies of Cirrhosis in Togo were hepatitis B virus
(57.2\%), C virus (25\%) and alcohol (18.7\%). Viral hepatitis is a provider of cirrhosis and $\mathrm{HCC}$, hence the interest of screening and vaccinating the Togolese population against viral hepatitis. $\mathrm{HCC}$ is the most common complication of liver cirrhosis affecting elderly people ${ }^{(20)}$. The rate of HCC increases with age in cirrhotic patients $^{(21)}$. HCV and HBV coinfection is a condition particularly prone to malignant transformation ${ }^{(22)}$. Another emerging condition that contributes to the development of HCC in old age is the non-alcoholic fatty liver disease (NAFLD). The hypothesis that obesity and diabetes mellitus are important risk factors for cryptogenic chronic liver disease in patients with HCC is supported by the analysis of surgically-treated patients ${ }^{(23)}$ : in a series of 18 patients who underwent liver resection for HCC developing on cryptogenic cirrhosis, 12 patients were $>65$ years of age. These observations have prompted the increasing interest in surveillance programs for cirrhotic patients, aiming to detect any HCC development as early as possible. Our present study did not allow us to specify the impact of NAFLD on the occurrence of HCC in the elderly. Pancreatic pathologies were dominated by cancer of the pancreatic head, whose care was done in a surgical environment; its frequency in our study is higher than that noted by Dibril et al. ${ }^{(5)}$ (three cases in eight years in patients aged 65 and more). Surgical resection is the only potentially curative treatment for pancreatic cancer ${ }^{(24,25)}$. Unfortunately, only $15 \%$ to $20 \%$ patients are candidates for pancreatectomy due to the late presentation of symptoms and/or detection of the disease ${ }^{(26,27)}$. Furthermore, the rate of resectability diminishes with age. Likewise, some authors reported that $40 \%$ of patients between the ages of $66-70$ years are candidates for a pancreatectomy, but by the age of 85 years, only $7 \%$ are eligible candidates ${ }^{(28,29)}$. Mortality due to pancreatic cancer also increases proportionally with age: $6.7 \%$ of patients aged $65-69$ years, $9.3 \%$ of patients aged $70-79$ years, and $15.5 \%$ of patients aged 80 years or older ${ }^{(24)}$. The frequency of peritoneal tuberculosis in the study by Djibril et al. ${ }^{(5)}(3 \%)$ was higher than that found in our study. In Mali, Dembélé et al. ${ }^{(30)}$, in two years, found 26 cases of peritoneal tuberculosis (associated with HIV) of which only one case $(3.85 \%)$ in a patient aged over 65 years. Peritoneal tuberculosis is much more common in young people who are immunocompromised by HIV, as noted by Bouglouga et al. ${ }^{(31)}$. Infectious pathologies are more common after age 60 because of age-related immune changes and iron deficiency ${ }^{(32)}$; the immunodepression with HIV found in these patients is a factor favoring the occurrence of this affection in this age group which constitutes a fragile ground. Food poisoning was the most common intestinal pathology followed by colorectal cancer; their frequency was lower in our study than that of Djibril et al. ${ }^{(5)}$. Fayomi et al. ${ }^{(33)}$ reported 29 cases of food poisoning, including one case in a male patient aged 60 years and more. We noted a frequency of $1.4 \%$ of colorectal cancers in agreement with the literature; colorectal cancers are typically rare in Africa, whose average age of diagnosis is around 50 years $^{(34)}$. The colon carcinoma is one of the most frequent lethal causes in the western countries; 90 per cent of the cases of colon carcinoma are found in patients older than 50 years of age ${ }^{(35)}$.

\section{The evolution of different digestive pathologies and the length of stay}

Cirrhosis was associated with a significant increase in the period of stay; this could be due to the impact of the complications of cirrhosis whose management in hospital could lead to a 
long hospital stay. The death was observed in case of cirrhosis in a significant way probably in connection with the complications of cirrhosis (ascitic decompensation, $\mathrm{HCC}$, infections, digestive bleeding) occurring on a fragile ground that the subject is 60 years old and more. Health insurance for public agents does not significantly change the hospital stay period. This health insurance which covers the cost of hospitalization of patients could explain the long stay of patients in category 1 room. Lawson-Ananissoh et al. ${ }^{(36)}$ in 2013 noted that health insurance for public agents, by covering a portion of patient expenses, has significantly reduced the direct financial cost of hospital care of cirrhosis. Overall, serious pathologies outside HCC had led to a long hospital stay and benign pathologies aside the bulbar ulcer had led to a short hospital stay; the very reserved prognosis of HCC could explain the short hospital stay of patients hospitalized for HCC unlike other cancers (pancreas, stomach); the hemorrhagic complication of bulbar ulcer could explain the long hospital stay unlike other benign pathologies; hemorrhagic complication is more common in bulbar ulcers than in gastric ulcers ${ }^{(37)}$. The delay in performing digestive fibroscopy due to financial difficulties or lack of technical support could contribute to increase the length of stay related to gastric cancer.

\section{CONCLUSION}

About one-fifth of the patients hospitalized in the Hepatology and Gastroenterology department of the Campus Teaching Hospital of Lome (Togo) were aged 60 and more and had a digestive pathology. Hepatobiliary pathologies were the most common, associated with a high rate of death and a long period of stay. Gastric cancer and cirrhosis were the main pathologies that led to a long hospital stay. Food poisoning was associated with a short hospital stay.

\section{ACKNOWLEDGEMENTS}

We thank Mr Soglo Apelete, the supervisor of the care units for his contribution in carrying out this work.

\section{Authors' contribution}

Lawson-Ananissoh LM is the principal initiator of this study. He participated in the data collection, statistical analysis and writing of this article. Bouglouga O, Bagny A, El-Hadji Yakoubou R participated in statistical analysis, data collection and bibliographic research. Kaaga L, Redah D participated in the reading and the final correction of this article.

Lawson-Ananissoh LM, Bouglouga O, Bagny A, El-Hadji Yakoubou R, Kaaga L, Redah D. Doenças digestivas em idosos e fatores associados à duração da permanência na unidade Hepatologia e Gastroenterologia do Hospital Universitário de Ensino de Lomé (Togo). Arq Gastroenterol. 2018;55(4):369-74.

RESUMO - Contexto - As patologias digestivas são frequentes no idoso e têm geralmente uma sintomatologia latente e atípica. Objetivo - Avaliar os dados epidemiológicos e de evolução sobre as doenças digestivas nos idosos, e procurar fatores associados ao período de permanência hospitalar. Métodos - Estudo retrospectivo de 10 anos, incluindo pacientes com idades de 60 ou mais, hospitalizados para doenças digestivas no Departamento de Gastroenterologia do Hospital Universitário de Ensino de Lomé, Togo. Resultados - De 5933 pacientes hospitalizados, havia 1054 pacientes (17,8\%) com idade de 60 anos ou mais com uma patologia digestiva (526 homens e 528 mulheres). A idade média foi de 69,5 anos $\pm 7,9$ variando de 60 a 105 anos. A duração média da estadia hospitalar foi de 7,45 dias $\pm 6,2$ variando de 1 a 44 dias. A prevalência do HIV foi de 2,4\%. Em ordem de diminuição da frequência, houve patologias hepatobiliares $(54,3 \%)$ com predominância de cirrose e câncer hepático, patologias do esôfago-gastroduodenal (23,1\%) com predominância de úlceras, câncer gástrico e câncer esofágico, patologias intestinais $(8,7 \%)$ com predominância de intoxicação alimentar, patologias pancreáticas $(4,2 \%)$ com predominância de câncer pancreático e patologia peritoneal $(1,4 \%)$. O câncer gástrico foi o segundo câncer digestivo encontrado após o câncer de fígado. Câncer de cabeça pancreática foi a segunda doença após o câncer gástrico, que necessitou transferência para a enfermaria cirúrgica $(P=0,31)$. Houve 204 mortes (19,4\%). A maior duração da internação foi devido ao câncer gástrico $(9,16$ dias). Conclusão - As doenças hepatobiliares foram as mais frequentes e associadas a uma elevada taxa de mortalidade e a uma longa estadia hospitalar.

DESCRITORES - Idoso. Doenças do sistema digestório. Hospitalização. Togo.

\section{REFERENCES}

1. Salles N. Pathologies digestives du sujet âgé. EMC Gastro-entérologie. 2012;7:1-11

2. Mahoungou Guimbi KC, Ellenga Mbolla F, Otiobanda GF, Ossou-Nguiet PM, Ndamba Banzouzi BY, Moyen G. Motifs d'admission et mortalité du sujet âgé de 60 ans et plus en réanimation polyvalente du CHU de Brazzaville. Ann Afr Med. 2011;5:957-63.

3. Tetchi Y, Abhé CM, Ouattara A, Coulibaly KT, Pete Y, Mevo S. Profil des affections du sujet âgé africain aux urgences médicales du CHU de Cocody Abidjan, Côte d'Ivoire. Journal Européen des Urgences et de Réanimation. 2013;25:147-51.

4. Statistiques mondiales, Togo. [Internet]. [Accessed 2016 July 05]. Available from: http://www.statistiques-mondiales.com/togo.htm.

5. Djibril MA, Bagny A, Bouglouga O, M'Ba O, Redah D, Agbetra A. Pathologies hospitalières du quatrième âge dans un service d'hépato-gastro-entérologie en milieu africain noir. Cas du CHU-Campus de Lomé (Togo). J. Rech. Sci. Univ. Lomé. 2011;13:39-45.

6. Atatsi A, Djibril MA, Balogou A, Pitche P, Amedegnato M, Agbetra A. Causes médicales d'hospitalisation des personnes âgées de 65 ans et plus au CHU Tokoin de Lomé. J. Rech. Sci. Univ. Lomé 2008;10:7-9.

7. Durazzo M, Premoli A, Bo S, Pellicano R. Gastrointestinal problems in the elderly. Panminerva Med. 2007;49:151-8.
8. Peghini M, Rajaonarison P, Pecarrere JL, Rakotozafindrabe R, Rakotoarivelo RA, Ramanampamonjy RM. Épidémiologie des cancers du tube digestif à Madagascar Apport de 14000 endoscopies effectuées au Centre Hospitalier de Soavinandriana à Antananarivo. Med Afr Noire. 1997;44:518-21.

9. Maïga YM, Diallo G, Dembélé M, Ndiaye M, Ongoiba N, Sanogo Z, et al. Cancer de l'œsophage : aspects épidémiologiques, cliniques et pronostiques. Acta Endoscopica. 2002;32:455-59.

10. Bouglouga O, Lawson-Ananissoh LM, Bagny A, Kaaga L, Redah D. Etude descriptive et analytique du cancer de l'œsophage au Togo. Pan Afr Med Journal. 2014;19:315.

11. Zeng Y, Liang W, Liu J, He J, Ng CSH, Liu CC. Esophageal cancer in elderly patients: a population-based study. J Thorac Dis. 2018;10:448-57.

12. Njei B, McCarty TR, Birk JW. Trends in esophageal cancer survival in United States adults from 1973 to 2009: a SEER database analysis. J Gastroenterol Hepatol. 2016;31:1141-6.

13. Mathieu LN, Kanarek NF, Tsai HL. Age and sex differences in the incidence of esophageal adenocarcinoma: results from the Surveillance, Epidemiology, and End Results (SEER) Registry (1973-2008). Dis Esophagus. 2014;27: 757-63. 
14. Torre LA, Bray F, Siegel RL. Global cancer statistics, 2012. CA Cancer J Clin 2015;65:87-108

15. Kadende P, Engels D, Ndoricimpa J, Ndabaneze E, Habonimana D, Marerwa G, et al. Les cancers digestifs au Burundi : Premiers résultats d'une enquête menée à Bujumbura. Med Afr Noire. 1990;37:552-61.

16. Bouglouga O, Lawson-Ananissoh LM, Bagny A, Kaaga L, Amegbor K. Cancer de l'estomac: aspects épidémiologiques, cliniques et histologiques au CHU Campus de Lomé (Togo). Med Sante Trop. 2015;25:65-8.

17. Diarra M, Diarra A, Dolo M, Kamate B, D’Horpock AF. Etude clinique, endoscopique, anatomo-pathologique et pronostique des cancers de l'estomac en milieu rural. Acta Endoscopica. 2005;35:237.

18. dos Santos Guedes MT, de Jesus JP, de Souza Filho O, Fontenele RM, Sousa AI. Clinical and epidemiological profile of cases of deaths from stomach cancer in the National Cancer Institute, Brazil. Ecancermedicalscience. 2014;8:445.

19. Bouglouga O, Bagny A, Djibril MA, Lawson-Ananissoh LM, Kaaga L, Redah D, et al. Aspects épidémiologiques, diagnostiques et évolutifs de la cirrhose hépatique dans le service d'hépato-gastro-entérologie du CHU Campus de Lomé. J. Rech. Sci. Univ. Lomé. 2012;14:1-7.

20. Floreani A. Liver Diseases in the Elderly: An Update. Dig Dis. 2007;25:138-43.

21. Ikeda K, Saitoh S, Suzuki Y, Kobayashi M, Tsubota A, Koida I, et al. Disease progression and hepatocellular carcinogenesis in patients with chronic vira hepatitis: a prospective observation of 2,215 patients. J Hepatol. 1998; 28: 930-38

22. Chiaramonte M, Stroffolini T, Vian A, Stazi MA, Floreani A, Lorenzoni U, et al: Rate of incidence of hepatocellular carcinoma in patients with compensated viral cirrhosis. Cancer. 1999;85:2132-7.

23. Regimbeau JM, Colombat M, Mognol P, Durand F, Abdalla E, Degott C, et al: Obesity and diabetes as a risk factor for hepatocellular carcinoma. Liver Transpl. 2004;2 (Suppl 1):S69-S73.

24. Higuera O, Ghanem I, Nasimi R, Prieto I, Koren L, Feliu J. Management of pancreatic cancer in the elderly. World J Gastroenterol. 2016;22:764-75.

25. Riall TS. What is the effect of age on pancreatic resection? Adv Surg. 2009;43: 233-49.

26. Riall TS, Reddy DM, Nealon WH, Goodwin JS. The effect of age on shortterm outcomes after pancreatic resection: a population based study. Ann Surg 2008;248:459-67.
27. Riall TS, Sheffield KM, Kuo YF, Townsend CM, Goodwin JS. Resection benefits older adults with locoregional pancreatic cancer despite greater short-term morbidity and mortality. J Am Geriatr Soc. 2011;59:647-54.

28. Sohn TA, Yeo CJ, Cameron JL, Lillemoe KD, Talamini MA, Hruban RH, et al. Should pancreaticoduodenectomy be performed in octogenarians? J Gastrointest Surg. 1998;2:207-16.

29. Meguid RA, Ahuja N, Chang DC. What constitutes a "highvolume hospital for pancreatic resection? J Am Coll Surg. 2008;206:622.

30. Dembélé M, Maiga MY, Minta DK, Traore SA, Sacko M, Traore AK, et al Tuberculose péritonéale dans un service de médecine interne en milieu tropical: aspects clinique, biologique et laparoscopique à Bamako-Mali. Acta Endoscopica. 2003;33:561-64

31. Bouglouga O, Bagny A, Djibril MA, Lawson-Ananissoh LM, M'ba F, Redah $\mathrm{D}$, et al. Tuberculose péritonéale et infection par le VIH chez l'adulte. Médecine Tropicale. 2011;71:3-4

32. Raschilas F. Épidémiologie des maladies infectieuses du sujet âgé. Soins Gerontol. 2006;11:22-6.

33. Fayomi B, Josse R, Adaye A, Laloe V, Djogbe H, Zohoun R. Toxi-infection alimentaire en milieu rural béninois. Med Afr Noire. 1992;39:364-6.

34. Sawadogo A, Ilboudo PD, Durand G, Peghini M, Branquet D, Sawadogo AB, Ouedraogo I. Epidémiologie des cancers du tube digestif au Burkina-Faso: Apport de 8000 endoscopies effectuées au Centre hospitalier National Sanou Souro (CHNSS) de Bobo Dioulasso. Med Afr Noire. 2000;47:342-45.

35. Reimann FM, Schreiber M, Leriche L, Bruning A, Stange EF. Gastrointestinal problems in elderly patients. Z Gerontol. Geriatr. 1997;30:208-19.

36. Lawson-Ananissoh LM, Bouglouga O, Bagny A, Kaaga L, El-Hadj Yakoubou $\mathrm{R}$, Redah D. Impact de l'assurance maladie sur le coût financier direct de la prise en charge médicale de la cirrhose au centre hospitalier et universitaire Campus de Lomé, Togo. J Afr Hépatol Gastroentérol. 2015;9:7-11.

37. Sombié R, Tiendrébéogo A, Guingané A, Hagège H, Lesgourgues B, Lamy V, et al. Hémorragie digestive haute : aspects épidémiologiques et facteurs pronostiques au Burkina Faso (Afrique de l'ouest). J Afr Hépatol Gastroentérol. 2015; 9:154-9 